\title{
The Management of the Coronavirus Emergency by the Italian Government and the Relationship between State and Regions
}

\author{
By Gloria Marchetti
}

\begin{abstract}
The essay analyses how the health emergency due to the spread of Covid-19 was handled in Italy. It is aimed at examining: the regulatory framework relating to the management of the pandemic; the role of State and Regions in adopting measures to contain the virus; the coordination between State and Regions to deal with the health emergency. In particular, the aim of the essay is to verify whether the State, in managing the pandemic, has respected the constitutional principles that underpin the Italian regional system.
\end{abstract}

Keywords: Coronavirus Emergency Regulation, State and Regions competences, State and Regions coordination, Italian Regional System, Principle of Loyal Cooperation.

\section{Introduction - The Regulation of the Emergency in Health Matters}

The aim of this essay is to offer a contribution to the ongoing debate on Italy's management of the Coronavirus emergency. This issue has sparked a wide debate among constitutional law scholars - as well as in public opinion - in relation to various problematic aspects, such as: respect of the system of sources of law in the period of the pandemic; the constitutional legitimacy of the suspension of fundamental rights and freedoms by the so-called «emergency measures»; the dialogue between Government and Parliament, within a parliamentary system, in emergency management; the relationship between the State and the autonomy system in the adoption of legislation aimed at tackling the health crisis.

This essay focuses on the latter of these problematic aspects. In this regard, it should be noted that, in the period of the pandemic, the issue relating to the role of the State and the Regions, in adopting emergency measures, has assumed a particular importance. This at least for two reasons. The first reason is that the spread of the virus has occurred in different ways in the regional territories and this has imposed the need to adopt different measures in the Italian Regions. The second reason is that, within the framework of a regional state model, the Italian Regions have important competences related to the health emergencies.

Therefore, it is useful to recall what the role of the State and the Regions is in the management of emergencies in general and, more specifically, in the field of health.

*Professor of Constitutional Law, Department of International, Legal, Historical and Political Studies, University of Milan, Milano, Italy. E-mail: gloria.marchetti@unimi.it. 
With regard to the distribution of administrative functions, the Constitutional Law no. 3 of 2001 (reform of Title V, part two, of the Constitution, governing the autonomy system) has enhanced the role of the entities closest to citizens, introducing the principle of subsidiarity. According to this principle, the administrative functions are attributed to the Municipalities, except in cases in which, in order to ensure their unitary exercise, they are assigned to larger territorial levels (Provinces, Metropolitan Cities, Regions and State), in application of the principles of subsidiarity, differentiation and adequacy (art. 118.1, Constitution).

As for the division of legislative powers between the State and Regions, the Constitutional Law no. 3/2001 has significantly strengthened the legislative autonomy of the ordinary Regions ${ }^{1}$. Following this reform, art. 117 of the Constitution contains: a list of matters in which the State has exclusive legislative power (art. 117.2); a list of matters in which the Regions have concurrent legislative power (art. 117.3), i.e. they can legislate but in compliance with the «fundamental principles of the matter» established by the State; a residual clause for which, in all matters not included in the two previous lists, the Regions have exclusive or residual legislative power (attributed only to Regions with special autonomy, with their own Statute containing the division of legislative powers, before the 2001 reform). In this general framework, the matters indicated in art. 117 of the Constitution concerning the health emergency are the following: the «protection of health» which is a concurrent competence of the State and Regions $^{2}$; the «public order and security» and «international prophylaxis» which are the exclusive competence of the State. This interweaving of competences makes it difficult to clearly define who is responsible for adopting legislation aimed at dealing with the COVID emergency. In addition, the Constitution contains a provision that allows the State to intervene to ensure adequate uniformity, on the national territory, in the protection and enjoyment of social rights.

The State, in fact, has exclusive competence to determine «the essential levels of services concerning civil and social rights that must be guaranteed throughout the national territory» (art. 117.2, lett. $m$ ), Constitution) $)^{3}$. The State, again in order to guarantee uniformity on the territory, can also legislate on regional matters, applying the mechanism of the so-called «attraction in subsidiarity». This mechanism was elaborated by the Constitutional Court, starting from sentence no. 303 of 2003; according to this mechanism, when the State, in application of the principle of subsidiarity, attracts administrative functions of the Regions (as required by art. 118 of the Constitution which, as we have seen, governs the division of administrative competences between the levels of government), it can also exercise legislative power in regional matters, in compliance with the principle of loyal collaboration with the Regions.

Furthermore, the Constitution enhances the role of the State in the management of emergencies, providing, for this purpose, a specific state source

\footnotetext{
${ }^{1}$ See Bilancia P. \& Scuto (2015).

${ }^{2}$ See Morana (2002); Ferrara (2012).

${ }^{3}$ See Papa (2019).
} 
of law. Art. 77 of the Constitution, in fact, gives the Government the power to adopt provisional measures having the force of law, in the form of law decrees, in «extraordinary cases of necessity and urgency»; these decrees must be presented on the same day for conversion to the Chambers, which must, within 60 days, convert them into law, otherwise they lose their effectiveness ex-tunc ${ }^{4}$. The law decree, therefore, is the most appropriate tool for dealing with situations of extraordinary emergency, also in order to «authorise» the use of the additional instrument that the legal system provides for dealing with such situations, namely the ordinances of necessity and urgency.

Ordinances of necessity and urgency are «extraordinary» administrative acts that can be adopted by the State, by the Regions and by local authorities in the cases expressly provided for by the law or, as we have seen, by a law decree, to deal with situations of needs that cannot be solved with the «ordinary» remedies provided for by the legal system. The ordinances, which represent the extrema ratio, allow the administration to deal with exceptional, serious and non-predeterminable situations by law ${ }^{5}$, also through the adoption of acts that can derogate the current legislation.

The problem is that ordinance powers are attributed, as will be seen below, to various institutional subjects and at various territorial levels. This can result in a fragmentation of the activity of adopting measures capable of compromising the adequate management of an emergency at a national level, such as that caused by COVID.

Law no. 833 of 1978 (that had established the Italian National Health Service (SSN)) attributes the power to adopt urgent ordinances in the field of «public health» to the Minister of Health, the President of the Region and the Mayor, depending on the territorial area concerned (art. 32). This provision is subsequently taken up - as well as by Legislative Decree no. 267 of 2000 (art. 50.5), in relation to the Mayor ${ }^{6}$ - by Legislative Decree no. 112 of 1998 which divides the competence to issue ordinances of necessity and urgency between the Ministry of Health, the Presidents of the Regional Councils and the Mayors, respectively on the national, regional or municipal territory (art. $117)^{7}$.

The Civil Protection Code (Legislative Decree no. 1 of 2018) provides that, upon the occurrence or imminence of one of the events expressly indicated, the Council of Ministers deliberates the national «state of emergency» (art. 24) which must be addressed with civil protection ordinances (art. 25). The latter are adopted by the Head of the Civil Protection Department, after having acquired the agreement of the Regions and Autonomous Provinces territorially concerned, in order to coordinate the interventions to be carried out during the state of emergency. Civil protection ordinances can be adopted in derogation from the provisions in force ${ }^{8}$ but within the limits and in the manner indicated

\footnotetext{
${ }^{4}$ See Tripodina (2020) at 82.

${ }^{5}$ Morbidelli (2016).

${ }^{6}$ Cavaggion (2017).

${ }^{7}$ Mangiameli (2006).

${ }^{8}$ See Constitutional Court ruling no. 44/2019.
} 
in the state of emergency resolution and in compliance with the general principles of the legal system (art. 25).

The Italian Constitution, therefore, unlike, for example, the German, French and Spanish ones, does not provide for a specific discipline for emergency ${ }^{9}$. In fact, in order to deal with «extraordinary» emergency situations, it only provides for the instrument of the law decree, while ordinary legislation provides, as mentioned above, the ordinances of necessity and urgency ${ }^{10}$.

On the other hand, finally, the Constitution provides for the possibility for the Government to intervene, as a substitute, in the case of inaction of the local authorities in the face of a «serious danger to public safety and security» (art. 120.2).

From the regulatory framework described so far, a model of emergency management emerges, in health matters, which does not provide for a separation of powers and competences between the levels of government, but for their integration $^{11}$. Consequently, even if an emergency situation, such as that due to the pandemic, requires a unitary action by the State, it must, in any case, respect the principles of autonomy and decentralisation, contained in art. 5 of the Constitution, and the constitutional principle of loyal collaboration between the State and the Regions. This principle was first developed by the Constitutional Court and subsequently introduced into the Constitution by the 2001 reform.

Therefore, the essay is aimed at analysing the measures adopted in the emergency period, in order to assess whether the State, faced with the need to manage the pandemic in a unified manner, has respected the constitutional principles of autonomy, decentralisation and loyal collaboration between the State and the Regions.

\section{Methodology in the Analysis of Topics covered and Expected Results}

The methodology used in the research on problems related to the management of the COVID emergency includes a careful analysis of the measures adopted, by the State and the Regions, to contain the virus. In addition, the essay takes into account the updated literature, capable of expressing the theoretical and scientific, as well as practical, findings of the problematic aspects addressed in this study.

A reconstruction of the legislation relating to emergency management is carried out, in order to assess how this legislation has disciplined the role of the State and the Regions, in adopting emergency measures, and defined their relations. Furthermore, the concrete behaviours of the subjects involved are analysed.

\footnotetext{
${ }^{9}$ Studies on the emergency regulation in Italy, on the occasion of the pandemic, have conducted by: Azzariti (2020); Cardone (2020) at 343; Caretti (2020); De Minico (2020); Comazzetto (2020); De Martin (2020); Onida (2020); Ravì Pinto (2020); Silvestri (2020); Sorrentino (2020). See also Bonetti (2020); Calamo Specchia (2020); Caravita (2020) at v-vi; Grosso (2020) at vi-vii.

${ }^{10}$ Raffiotta (2020).

${ }^{11}$ See Dell'Atti \& Naglieri (2020).
} 
The methodological approach is the legal and practical one and the conclusions are aimed at demonstrating how the management of the emergency has further contributed to highlighting the limits of a structure of relations between the State and the Regions that has actually been created, over time, but which, very often, does not appear consistent with constitutional principles.

Therefore, the expected result of the research is to identify some possible solutions that could be adopted, in dealing with the health emergency that would be more respectful of the autonomy principle that characterises the Italian Constitution.

\section{The Legislation on Pandemic Management: The Role of the State and the Regions and their Weak Coordination}

Therefore, the legislation relating to the management of the pandemic, the role of the State and the Regions in the adoption emergency measures and their coordination will be reconstructed below.

The first state measure relating to the pandemic was adopted on 31 January 2020 by the Council of Ministers; the latter approved a «state of national emergency» for six months - subsequently extended - due to the health risk associated with COVID-19, providing for the adoption of ordinances by the Head of the Civil Protection Department, «in derogation of existing provision and in compliance with the general principles of the legal system»12. It has been seen that the Civil Protection Code provides that for the adoption of the ordinances it is necessary to acquire the agreement of the Regions and Autonomous Provinces territorially concerned. However, the state of emergency resolution does not mention this obligation, indeed it does not provide for any form of consultation with the Regions 13 .

In the first phase of the emergency, numerous measures were adopted that included severe restrictions on freedoms, up to the point of introducing the lockdown throughout the national territory. Initially, the emergency was dealt with by the State through the adoption of two law decrees: the Law Decree of 23 February 2020, no. 6 and the Law Decree of 25 March 2020, no. 1914.

The Law Decree no. 6/2020 has regulated the role of the State and the Regions in adopting emergency measures and their mutual relations. The decree shows the will of the Government to play a strong role in the management of the emergency. The decree, in fact, provided that the emergency measures were adopted by the President of the Council of Ministers with one or more decrees, after a simple consultation of the Regions (art. 3.1).

\footnotetext{
${ }^{12}$ See: Algostino (2020) at 117-121; Dolso (2020).

${ }^{13}$ See Catelani (2020b).

${ }^{14}$ See: Belletti (2020); Cherchi \& Deffenu (2020); Cintioli (2020); De Siervo (2020); Di Cosimo (2020). In particular, the following authors have analysed the problems linked to the use of the law decree and the decrees of the President of the Council of Ministers to deal with the emergency, also in relation to the system of sources of law: D'Aloia (2020); Fabiano (2020); Lauro (2020); Longo \& Malvicini (2020); Lucarelli (2020); Massa Pinto (2020); Mazzarolli (2020); Mobilio (2020); Ronga (2020); Rossi (2020); Trabucco (2020); Tresca (2020) at 207-211.
} 
On the other hand, the decree authorised the Presidents of the Regions and the Mayors to issue, even in the emergency phase, ordinances on health matters, on the basis of the pre-existing legislation (examined above) (art. 3.2). The decree, however, provided for two limits to the power of ordinance of Regions and Municipalities: it could only be exercised until the adoption of the decree of the President of the Council of Ministers and only in cases of «extreme necessity and urgency». Therefore, the measures contained in the regional ordinances would have been applied until the adoption of a conflicting discipline through a decree of the President of the Council of Ministers. The purpose of these limitations on the powers of ordinance was to prevent the decrees of the President of the Council of Ministers from being overwhelmed by a series of ordinances of the Regions and Municipalities ${ }^{15}$. In reality, the decree in question, providing for the possibility of adopting, in a generic way, «further measures», still left the Regions with a rather vast power of ordinance, not subject to any control or to the obligation of collaboration with the State. For this reason, in the period following the decree, many contingent and urgent ordinances have been adopted by the Regions ${ }^{16}$. In some cases, regional ordinances have provided for more restrictive measures on citizens' freedom than State ones ${ }^{17}$. This situation has created tensions in the relations between the Government and some Regions (in particular with Lombardy and Campania) since the first days of the emergency ${ }^{18}$.

Subsequently, the Law Decree no. 19/2020 further strengthened the role of the Government, in emergency management, and better defined the relations between the State and the Regions. Similarly to the previous one, the decree provided for a limited involvement of the Regions in State decisions. The competence of the President of the Council of Ministers to adopt decrees containing measures to limit the spread of the virus has been confirmed, after consulting the Presidents of the Regions or the President of the Conference of Regions and Autonomous Provinces (the body that represents the respective interests), depending on the territory concerned (individual Regions or the entire national territory) (art. 2). Furthermore, the decree, in order to standardise the virus containment measures, at a national and regional level, and to limit the interventions of the Regions, introduced more stringent limits to the power of regional ordinance. In fact, the possibility was envisaged for the Regions to introduce further restrictive measures, compared to those provided for by the decree, only in the context of the activities within their competence (with the exclusion of productive activities and of strategic importance for the national economy) exclusively in case of an aggravation of the health risk on their territories (or in a part of them) (art. 3.1). It was also confirmed that regional ordinances can only be adopted pending the adoption of the Decree of

\footnotetext{
${ }^{15}$ Carlesimo (2020).

${ }^{16}$ See Bartolini \& Ruggiero (2020); Bignami (2020); Di Capua (2020) and Musella (2020), who have conducted studies on the use of regional ordinances in the emergency period.

${ }^{17}$ See Pinelli (2020).

${ }^{18}$ The following authors in particular have highlighted the problems related to the relations between the State and the Regions in the management of the health emergency: Cortese (2020); Ferraiulo (2020); Mandato \& Stegher (2020).
} 
the President of the Council of Ministers and that, subsequently, they lose their effectiveness 19. Finally, the decree, unlike the previous one, provided that, pending the adoption of the Decree of the President of the Council of Ministers, the competence to adopt acts, with limited effectiveness until that moment, in cases of «extreme necessity and urgency», for unexpected situations, is of the Minister of Health20 and no more of the President of the Region and the Mayor. The provision of a power of the Regions to derogate in peius highlights the will of the legislator to centralise the choices in the hands of the Government 21 .

Nevertheless, the decree did not precisely define the conditions and limits for the adoption of regional measures and did not provide for forms of preventive collaboration with the State (not even a consultation). The Regions, therefore, have continued to adopt ordinances which, in many cases, have introduced further limitations with respect to those envisaged at the State level22; this is because the Presidents of some Regions regarded the Government measures as inadequate and insufficient. Some of these ordinances, however, did not respect the limits identified by Law decree no. $19 / 2020$, having been adopted even in cases where there was no worsening of the health situation.

With the launch of the so-called «phase 2», the State legislation, in order to weaken emergency measures, has outlined a different structure of relations between the State and the Regions to cope with the pandemic23. The Law Decree of 16 May 2020, no. 33 established that, from 18 May to 31 July 2020, with State, Regional or Municipal decrees and ordinances, the movement of people and the methods of carrying out economic, productive and social activities could be regulated. In this framework, greater powers of monitoring the epidemic have been attributed to the Regions and the possibility of adopting, consequently, adequate measures. The Regions were called to monitor the progress of the epidemiological situation of their territories, on a daily basis, and to communicate the relevant data to the Minister of Health, the Italian National Institute of Health and the Technical-Scientific Committee set up at the Department of Civil Protection (which provides advice on the adoption of emergency measures). The Regions were given the possibility, in relation to the progress of the epidemiological situation in their territories and pending the adoption of the Decree of the President of the Council of Ministers, to introduce derogatory, broadening or restrictive measures, compared to those established at the State level24. Some Regions, however, had already begun, even before the Decree no. 33/2020, to adopt less restrictive measures than those envisaged by the State (e.g. the Veneto and Campania Regions). As for the collaboration between the State and the Regions, the

\footnotetext{
${ }^{19}$ See: Luciani (2020); Pollicino \& Vigevani (2020).

${ }^{20}$ Pursuant to art. $32,1.833 / 1978$.

${ }^{21}$ Boggero (2020).

${ }^{22}$ See De Marco (2020) at 373.

${ }^{23}$ See D'Amico (2020) at 22-25.

${ }^{24}$ Salerno (2020).
} 
decree provided that: the ordinance of the Minister of Health identifying one or more Regions in which additional measures (identified by a decree of the President of the Council of Ministers) may be applied, with respect to those provided on the national territory, are adopted after hearing the Presidents of the Regions concerned; the ordinances of the Minister of Health which provide for the application, in relation to specific parts of the regional territory, of measures envisaged for the entire national territory, are adopted in agreement with the Presidents of the Regions concerned. Greater collaboration between the State and the Regions had already been contemplated also by the Decree of the Minister of Health of 30 April 2020; it provided that, at central level, any re-evaluation of health risks takes place in agreement with the Region concerned and the collection of the necessary information to classify the risk takes place through a specific Control Room, which involves the Regions and the Italian National Institute of Health. Despite these provisions, however, the conflict between the Government and the Regions continued even during «phase 2» of the pandemic. In some cases, in fact, the Presidents of the Regions have continued to adopt ordinances that do not comply with the limitations envisaged by the Government ${ }^{25}$.

So much so that the State has, in some cases, appealed these ordinances before the competent Administrative Judge. The Courts have sometimes recognised the validity of regional ordinances - as they are based on the power to adopt further measures related to specific situations of the Regions - while, in other cases, they have, instead, agreed with the State. For the purpose of greater coordination between the State and the Regions, a Document of «Prevention and response to COVID-19: evolution of strategy and planning in the transition phase for the autumn-winter period» was therefore prepared, shared by the Conference of Regions, composed of Presidents of the Regions, on 8 October 2020. In this regard, it appears positive that there has been a sharing between the State and the Regions on the tools and measures aimed at a remodelling of the containment measures of the pandemic, based on the risk situation in each Region.

Finally, starting from November 2020, in conjunction with the increase in the number of COVID cases, a new phase in the management of the pandemic has begun which has provided for the territorial mini-lockdowns and the return to severe restrictions on economic, productive and social freedoms and activities. In this context, measures have been adopted that are no longer aimed, as in the first phase of the emergency, at closing activities and limiting freedoms in a generalised manner. With the adoption of the Decree of the President of the Council of Ministers on 3 November 2020, a national emergency management model was adopted: national rules were introduced and apply to the whole territory, which can be modulated in areas of different colours (yellow, orange, red), corresponding to different levels of criticality in the Regions, and increasing restrictions are applied in relation to the risk. The risk areas are determined on the basis of data provided by the Regions and are

\footnotetext{
${ }^{25}$ Significant, for example, the adoption, by the Calabria Region, of a provision which, anticipating decisions that would then have also adopted by the Government, has authorised the reopening of certain commercial activities, suspended by the decree no. 19/2020.
} 
considered according to the Risk Index (i.e. the contagiousness index) and other risk factors (21 factors, including, e.g., the employment rate of intensive care). The involvement of the Regions in the adoption of the decrees of the President of the Council of Ministers is guaranteed through participation in the decisions of the Control Room and by the procedural process that foresees hearing the President of the Conference of Regions. Similarly, the ordinances of the Minister of Health are adopted after consultation with the Presidents of the Regions concerned, on the basis of the Document of prevention and response to COVID and of the data processed by the Control Room. In the case of ordinances by the Minister of Health that exempt some parts of the regional territory from compliance with certain measures, due to the trend of epidemiological risk, an agreement is envisaged with the Region concerned. In this framework of national emergency management, the Regions have been entrusted with a monitoring role and the possibility of adopting more restrictive measures than those of the State.

The Decree of the President of the Council of Ministers of 14 January 2021 also introduced the possibility of providing a «white zone», which is added to the three coloured area, yellow, orange and red. In this area, in the face of a sharp decline in infections and a low risk (with an incidence of infections for two consecutive weeks of less than 50 cases per 100,000 inhabitants), almost all activities may be able to resume and restrictive measures can cease to apply. In any case, ad hoc restrictive measures linked to the relevant activities from an epidemiological point of view may be adopted in the white zone, again with Decree of the President of the Council of Ministers. The mechanism for inserting a Region in the white zone is the same used up to that moment to insert the Regions in the yellow, orange or red zone: an ordinance of the Minister of Health must be adopted. Therefore, at the time of writing, each Region is expected to be included in one of the four areas, each of which has different rules to respect.

The Regions, however, always have the power to issue more restrictive measures than those decided by the Government. In addition to the measures envisaged for each area, there are also limitations that apply throughout the national territory. These measures - contained in the Decree of 14 January 2021 and valid until 5 March 2021 - are, at the time of writing, contained in the Decree of the President of the Council of Ministers of 2 March 2021 and applied from 6 March 2021 to 6 April 2021. Even in this phase there have been conflicts between the Regions and the State. Some Regions have harshly criticised the decisions of the Government that have foreseen their insertion in a specific area and have appealed to the Administrative Judge against the State provision (e.g. Lombardy and Sardinia Regions). On the other side, the Government appealed to the Constitutional Court against the Valle d'Aosta Regional Law of 9 December 2020, n. 11 - which allowed the carrying out of a series of activities in derogation from the provisions of State legislation and the Court suspended, for the first time, a regional law as a precautionary measure (ordinance no. 4 of 2021)26. More generally, then, the Presidents of

${ }^{26}$ See Dickmann (2021). 
some Regions (Lombardy, Friuli Venezia Giulia, Sardinia, Calabria, Umbria and Veneto) have asked the State to review the procedures for determining the colour of the Regions; they claimed the need to provide for procedures aimed at ensuring a greater regional role, with regard to choices relating to their territories, and an effective participation in the adoption of State decisions.

\section{Research Results. The Violation of the Constitutional Principles of the Regional System by the Emergency Legislation}

To cope with the pandemic, the State has adopted a model of centralisation of competences ${ }^{27}$ accompanied by weak collaboration between the Government and the Regions ${ }^{28}$.

On the one hand, the emergency decrees have left the Regions a residual role, allowing their intervention only in the cases and within the limits expressly regulated. The State discipline should have left the Regions with greater possibilities of intervention, both because of their competences in health matters and because the spread of the virus took place differently in the various regional territories. This might have avoided the adoption of regional ordinances that were not in line with State measures ${ }^{29}$. Furthermore, the limited role of the Regions has prevented the development of more targeted territorial policies which would probably have made even the State measures more efficient.

On the other hand, the State legislation on the emergency provided for a weak collaboration between the Government and the Regions, based on a mandatory but not binding comparison ${ }^{30}$. No institutionalised procedures for comparison with the Regions have been regulated ${ }^{31}$. For the adoption of Government decisions, in fact, an opinion or an agreement was not required; the Regions were asked to share the choices of the Government, since the latter could adopt the measure even in case of disagreement ${ }^{32}$.

This has led to have only an informal cooperation between the Government and the Regions ${ }^{33}$. And even if, in the second phase of emergency management, there was greater consultation with the Conference of Presidents of the Regions, this always took place at an informal level. The Government's measures, therefore, were not the result of a joint and coordinated activity with the Regions, within the system of Conferences ${ }^{34}$. In Italy, in the absence of a Chamber of Autonomies, the system of Conferences (consisting of the State-Regions and Autonomous Provinces Conference, the State-Local Autonomies Conference, representative bodies of the respective levels of government, and the Unified

\footnotetext{
${ }^{27}$ Cavino (2020).

${ }^{28}$ Longo (2020).

${ }^{29}$ See Melzi d'Eril \& Vigevani (2020).

${ }^{30}$ See Di Cosimo \& Menegus (2020); Clementi (2020); Formisano (2020).

${ }^{31}$ Camerlengo (2020).

${ }^{32}$ Severa (2020).

${ }^{33}$ See Delledonne \& Padula (2020); D’Orlando (2020).

${ }^{34}$ Catelani (2020a).
} 
Conference which brings together the members of the other two conferences) represents the interests of the various levels of government at central level.

Greater consultation, moreover, would have allowed the Government to take into greater consideration, at least in the first phase of the emergency, the needs of individual Regions that have been most affected by the pandemic. Instead, the Government, until the autumn of 2020, preferred to deal with the emergency in a uniform way, providing for the same measures in all Regions, and unilaterally, in the absence of a real agreement with the latter. The Regions have reacted to State centralisation by adopting, as we have seen, many ordinances that were not always in line with the indications of the Government. Furthermore, an attitude of protagonism of the Presidents of the Regions has often emerged; they have tried to demonstrate their commitment in the fight against the pandemic - by contrasting with the decisions of the Government - also in order to have visibility on the media and obtain consensus 35. Moreover, even the Regions have adopted measures without coordination with the Government; in fact, only in a few cases Regional ordinances have been adopted in agreement with the State (e.g. the ordinances of the EmiliaRomagna, Friuli Venezia Giulia, Liguria, Lombardy, Piedmont and Veneto Regions, adopted on 23 February 2020). In this regard, it is evident that the contrasts between the Regional ordinances and the Decrees of the President of the Council of Ministers were the consequence of inadequate coordination between the various levels of government. This has led - as we have seen above - the State and some Regions to confront also before the Administrative Judge and the Constitutional Court. It cannot therefore be denied that the dialogue between the State and the Presidents of the Regions has often been difficult and conflicting even if the will, on the part of both levels of government, seems to have prevailed, to avoid an institutional breakdown in managing an unprecedented emergency in the republican history.

What we want to highlight in this essay is that it does not seem that the State, in managing the pandemic, has respected the constitutional principles that underpin the Italian regional state. It is true that the State had to consider the need for a unitary management of the epidemic throughout the country and the urgency to act quickly. It is also true, however, that an excessive sacrifice of regional autonomy and of the constitutional principle of loyal cooperation between the State and the Regions is not admissible, not even in the face of the urgency of providing for the unitary measures36. Nevertheless, from the analysis carried out, it emerges that the State, in dealing with the health emergency, has not respected the constitutional principles that characterise the Italian regional system.

Firstly, the emergency decrees have excessively limited the role of the Regions, in violation of the autonomy principle. Especially in the first phase of

\footnotetext{
${ }^{35}$ See Bilancia F. (2020); Bin (2020); Furlan (2020).

${ }^{36}$ Many authors have analysed the issue of centralised or decentralised management of the pandemic: Allegretti (2020); Betzu \& Ciarlo (2020); Balboni (2020); Di Cosimo \& Cossiri (2020); Chieffi (2020); Buzzacchi (2020); Lanzafame (2020); Malo (2020); Morelli \& Poggi (2020); Pagano (2020); Palermo (2020); Staiano (2020).
} 
the pandemic, in fact, there was a progressive centralisation of powers, in order to manage the emergency, by the National Government and, in particular, by the President of the Council. Nonetheless, one of the cardinal principles of the Italian Constitution is the autonomy principle which must be implemented through a pluralism of entities: State and Regional and Local Autonomies which enjoy, pursuant to art. 114 of the Constitution, the same constitutional dignity and are placed in a relationship of equi-ordination and not of subordination.

Secondly, the emergency legislation has not adequately taken into account the Italian regional state model which requires, among other things, that relations between the State and the Regions are based on the principle of loyal collaboration. A collaboration based only on the obligation to hear the Regions does not seem able to guarantee effective coordination between the levels of government. Being measures adopted in matters in which, as we have seen, there is an intertwining of state and regional competences, the application of the principle of loyal cooperation between the State and the Regions would have required the provision of stronger cooperation instruments ${ }^{37}$, such as the agreement or understanding; tools, therefore, aimed at obtaining a consensus from the Regions and addressing the emergency in a more coordinated manner ${ }^{38}$. In fact, the principle of collaboration between entities, as often recalled by the Constitutional Court, must be applied in cases of exercise of competences and functions affecting the different levels of government, in order to avoid overlapping of competences and invasions of the sphere of regional autonomy.

\section{Conclusions}

The picture that emerges is that of an emergency regulation of a competitive and conflictual nature between the State and the Regions.

Although there was a willingness, on the part of both levels of government, to avoid an institutional breakdown, there was not even a coordinated action of comanagement of the emergency and an effective involvement of the Regions in the adoption of State measures, nor of the Government, for the adoption of the Regional ones ${ }^{39}$. Therefore, a State and Regional attitude which largely neglected the Constitutional principles that underpin the Italian regional system, prevailed, in the name of greater effectiveness of the respective actions.

This has fuelled the tension between unity and autonomy that characterises the Italian regional system40. Faced with an intertwining of competences between the State and the Regions, in the field of health emergencies, and a different degree of risk in the various regional territories, both the central instances of unity and homogeneity and the local instances should have been considered. It does not seem, however, that the two fundamental needs of a

\footnotetext{
${ }^{37}$ Equizi (2020).

${ }^{38}$ Mandato (2020).

${ }^{39}$ Poggi (2020).

${ }^{40}$ Baldini (2020).
} 
regional system have been balanced: the need for unity and the need for differentiation.

The unitary and centralised management of the emergency and the absence of adequate legislation that respects the principle of loyal collaboration between the levels of government have demonstrated the limits of the effective functioning of the Italian regional system. Even if the Constitution, after the 2001 reform, outlines a cooperative regionalism, in reality this has never been realised. In this vein, even on the occasion of the management of the COVID emergency, the need to respect the principle of loyal collaboration between the State and the Regions was not adequately taken into account, in order to prevent one level from prevailing over another, reinforce a non-competitive cooperative regionalism model41. Indeed, it seems that during the period of health emergency, a model of cooperative regionalism was neglected42. This model could have limited the conflicts between the State and the Regions and would have better reconciled the need to manage the epidemic in a unitary manner, throughout the national territory, and the need to recognise adequate regional powers to deal with the specific health situations of some territories. Moreover, the failure to comply with the principle of loyal collaboration between the State and the Regions has led to a myriad of legislative acts that have caused interpretative doubts and coordination difficulties, with inconveniences for citizens 43 .

The attitude taken during the pandemic requires a conclusive reflection on State-Regions relations within the Italian regional system. Somehow the exceptional nature of the health situation may suggest that it is permissible to neglect a concrete collaboration between the State and the Region in the adoption of the related measures. But this approach would not be compatible with the Italian constitutional model. The principle of loyal collaboration is essential for the maintenance of State-Regions relations and also of a decentralised constitutional system. Therefore, as it has already been highlighted, the unitary needs of the emergency do not justify either a centralisation of the Government's powers or the lack of effective coordinated action between the State and the Regions44. Indeed, it is especially in emergency situations that the separation of competences model is inadequate to cope with it but, on the contrary, coordinated action between the entities is required to adopt more effective solutions; solutions capable of reconciling, in fact, the need for centralised decisions which, however, take into account local needs.

\footnotetext{
${ }^{41}$ Cosulich (2020).

${ }^{42}$ In the opposite sense, Allegretti \& Balboni (2020).

${ }^{43}$ Rescigno (2020).

${ }^{44}$ Ruggeri (2020).
} 


\section{References}

Algostino, A. (2020). 'Covid-19: primo tracciato per una riflessione nel nome della Costituzione' (Covid-19: first path for a reflection in the name of the Constitution), in Osservatorio AIC 3: 116-125. Retrieved from: https://www.osservatorioaic.it/.

Allegretti, U. (2020). 'Una normativa più definitiva sulla lotta all'epidemia del coronavirus?' (A more definitive legislation on the fight against the coronavirus epidemic?) in Forum di Quaderni Costituzionali 1:519-520.

Allegretti, U. \& E. Balboni (2020). 'Autonomismo e centralismo nella lotta contro la pandemia coronavirus' (Autonomism and centralism in the fight against the coronavirus pandemic) in Forum di Quaderni costituzionali 1:536-546.

Azzariti, G. (2020). 'Il diritto costituzionale d'eccezione' (The constitutional law of exception) in Costituzionalismo.it 1: I-V.

Balboni, E. (2020). 'Autonomie o centralismo contro il coronavirus' (Autonomies or centralism against the coronavirus) in Quaderni Costituzionali 2:373-375.

Baldini, V. (2020). 'Emergenza sanitaria nazionale e potere di ordinanza regionale. Tra problema di riconoscibilità dell'atto di giudizio e differenziazione territoriale delle tutele costituzionali' (National health emergency and regional ordinance power. Between the problem of recognisability of the judgment act and territorial differentiation of constitutional protections) in Dirittifondamentali.it 1 885-892.

Bartolini, A. \& Ruggiero, F. (2020). 'Sull'uso (e abuso) delle ordinanze emergenziali regional' (On the use (and abuse) of regional emergency ordinances) in Rivista Giustizia insieme, April 23. .

Belletti, M. (2020). "La "confusione" nel sistema delle fonti ai tempi della gestione dell'emergenza da Covid-19 mette a dura prova gerarchia e legalità ' (The "confusion" in the system of sources at the time of the emergency management from Covid-19 puts a strain on hierarchy and legality) in Osservatorio AIC 3:174-199.

Betzu, M. \& P. Ciarlo (2020). 'Epidemia e differenziazione territoriale' (Epidemic and territorial differentiation) in BioLaw Journal 1: 201-208. http://dx.doi.org/10.15168/ 2284-4503-577

Bignami, M. (2020). 'Le fonti del diritto tra legalità e legittimità nell'emergenza sanitaria' (The sources of law between legality and legitimacy in the health emergency) in Questione giustizia 2:11-20.

Bilancia, F. (2020). 'Ragionando "a freddo": gli effetti della crisi emergenziale sui rapporti istituzionali Stato-Regioni' ("Cold" reasoning: the effects of the emergency crisis on State-Regions institutional relations) in Le Istituzioni del federalismo, special iusse: 29-38.

Bilancia, P. \& F. Scuto (2015). 'La riforma costituzionale tra superamento del bicameralismo paritario e riordino delle competenze Stato-Regioni' (The constitutional reform between overcoming the equal bicameralism and reorganizing the State-Regions competences), Research Paper, Centro Studi sul Federalismo. http://www.csfederalismo.it/it/pubblicazioni/research-paper/1106-la-riforma-costitu zionale-tra-superamento-del-bicameralismo-paritario-e-riordino-delle-competenzestato-regioni

Bin, R. (2020). 'Se la nostra salute è minacciata da uno spot politico' (If our health is threatened by a political spot) in LaCosituzione.info 9 March.

Boggero, G. (2020). 'Un decentramento confuso, ma necessario. Poteri di ordinanza di Regioni ed enti locali nell'emergenza da COVID-19' (A confused but necessary decentralisation. Ordinance powers of Regions and local authorities in the COVID-19 emergency) in Il Piemonte delle Autonomie 1:1-8. 
Bonetti, P. (2020). 'La Costituzione regge l'emergenza sanitaria: dalla pandemia del coronavirus spunti per attuarla diversamente' (The Constitution governs the health emergency: from the coronavirus pandemic, ideas for implementing it differently) in Osservatorio sulle Fonti 2:689-739.

Buzzacchi, C. (2020). 'Coronavirus e territori: il regionalismo differenziato coincide con la "zona gialla"' (Coronavirus and territories: differentiated regionalism coincides with the "yellow zone") in LaCosituzione.info 2 March.

Calamo Specchia, M. (2020). 'Principio di legalità e stato di necessità al tempo del "COVID-19"' (Principle of legality and state of necessity at the time of "COVID19") in Osservatorio AIC 3: 142-173.

Camerlengo, Q. (2020). 'Il governo della pandemia tra Stato e Regioni: ritorno al coordinamento tecnico' (The government of the pandemic between State and Regions: return to technical coordination) in Le Regioni 4:739-752.

Caravita, B. (2020). 'L'Italia ai tempi del coronavirus: rileggendo la Costituzione italiana' (Italy at the time of the coronavirus: re-reading the Italian Constitution) in federalismi.it 6:iv-x.

Cardone, A. (2020). 'Il baratro della necessità e la chimera della costituzionalizzazione: una lettura della crisi delle fonti del sistema di protezione civile contro le battaglie di retroguardia' (The abyss of necessity and the chimera of constitutionalisation: a reading of the crisis of the sources of the civil protection system against the rearguard battles) in Osservatorio sulle fonti, special issue:313-350.

Caretti, P. (2020). 'I riflessi della pandemia sul sistema delle fonti, sulla forma di governo e sulla forma di Stato' (The reflections of the pandemic on the system of sources, on the form of government and on the form of state) in Osservatorio sulle fonti, special issue:295-298.

Carlesimo, V. (2020). 'La gestione della pandemia da parte del Governo e il rapporto StatoRegioni' (The government's management of the pandemic and the State-Regions relationship) in Diritto.it:October 16.

Catelani, E. (2020a). 'Centralità della Conferenza delle Regioni e delle Province autonome durante l'emergenza Covid-19? Più forma che sostanza' (Centrality of the Conference of Regions and Autonomous Provinces during the Covid-19 emergency? More form than substance) in Osservatorio sulle fonti, special issue:501-515.

Catelani, E. (2020b). 'Il rapporto tra Stato e Regioni al tempo del Coronavirus: una premessa' (The relationship between State and Regions at the time of the Coronavirus: a premise) in Rivista del Gruppo di Pisa 2:3-10.

Cavaggion, G. (2017). 'L'abuso delle ordinanze sindacali contingibili e urgenti, non rimediato dal d.l. Minniti' (The abuse of contingent and urgent ordinances of the Mayors, not remedied by the legislative decree Minniti) in Il Piemonte delle Autonomie 2:1-15.

Cavino, M. (2020). 'Sulla illegittimità costituzionale dei decreti legge adottati per fronteggiare l'emergenza Covid-19' (On the constitutional illegitimacy of the law decree adopted to deal with the Covid-19 emergency), in M. Malvicini, T. Portaluri \& A. Martinengo (Eds) Le parole della crisi. Le politiche dopo la pandemia. (The words of the crisis. Politics after the pandemic) pp. 49-58. Naples: Editoriale Scientifica.

Cherchi, R. \& A. Deffenu (2020). 'Fonti e provvedimenti dell'emergenza sanitaria Covid19: prime riflessioni' (Sources and measures of the Covid-19 health emergency: initial reflections) in Diritti regionali 1:648-678.

Chieffi, L. (2020). 'La tutela del diritto alla salute tra prospettive di regionalismo differenziato e persistenti divari territoriali' (The protection of the right to health 
between perspectives of differentiated regionalism and persistent territorial divides) in Nomos. Le attualità del diritto 1:1-37.

Cintioli, F. (2020). 'Sul regime del lockdown in Italia (note sul decreto-legge n. 19 del 25 marzo 2020)' (On the lockdown regime in Italy (notes on decree-law no. 19 of 25 March 2020)) in federalismi.it. Osservatorio Emergenza Covid-19:1-16.

Clementi, F. (2020). 'Resta debole il coordinamento tra il governo e le Regioni' (Coordination between the Government and the Regions remains weak) in Il Sole 24 Ore, March 26.

Comazzetto, G. (2020). 'Lo stato di eccezione nell'ordinamento italiano. Riflessioni a partire dalle misure di contenimento dell'emergenza epidemiologica da CoViD-19' (The state of exception in the Italian legal system. Reflections starting from the containment measures of the epidemiological emergency from CoViD-19) in BioLaw Journal 1:35-42. http://dx.doi.org/10.15168/2284-4503-558

Cortese, F. (2020). 'Stato e Regioni alla prova del coronavirus' (State and Regions to the test of coronavirus) in Le Regioni 1:3-10.

Cosulich, M. (2020). 'Lo Stato regionale alla prova dell'emergenza virale' (The regional state to the test of the viral emergency) in Amministrazione In Cammino: 1-5.

D'Aloia, A. (2020). 'Postilla. Costituzione ed emergenza: verso la fine del tunnel, con qualche speranza e (ancora) con qualche dubbio' (Postil. Constitution and emergency: towards the end of the tunnel, with some hope and (still) with some doubts) in BioLaw Journal 1: 7-12.

D’Amico, M. (2020). 'Emergenza, diritti, discriminazion' (Emergency, rights, discrimination) in Rivista Gruppo di Pisa 3:16-42.

Dell'Atti, L. \& G. Naglieri (2020). 'Le fonti della crisi. Fra esigenze unitarie e garanzie costituzionali nel governo dell'emergenza da Covid-19' (The sources of the crisis. Between unitary needs and constitutional guarantees in the government of the emergency from Covid-19) in BioLaw Journal 1:135-143.

Delledonne, G. \& Padula, C. (2020). 'Accentramento e differenziazione nella gestione dell'emergenza pandemica' (Centralisation and differentiation in pandemic emergency management) in Le Regioni 4:753-780.

De Marco, E. (2020). 'Situazioni di emergenza sanitaria e sospensioni di diritti costituzionali' (Health emergency situations and suspensions of constitutional rights) in Consulta Online 2:369-377.

De Martin, G.C. (2020). 'Democrazia e stato di emergenza' (Democracy and a state of emergency) in Amministrazione In Cammino:1-6.

De Minico, G. (2020). 'Costituzionalizziamo l'emergenza?' (Shall we constitutionalise the emergency?) in Osservatorio sulle fonti, special issue: 541-564.

De Siervo, U. (2020). 'Emergenza Covid e sistema delle fonti: prime impressioni' (Covid Emergency and system of sources: first impressions) in Osservatorio sulle fonti, special issue:299-312.

Di Capua, V. (2020). 'Il nemico invisibile. La battaglia contro il Covid-19 divisa tra Stato e Regioni' (The invisible enemy. The battle against Covid-19 divided between State and Regions) in federalismi.it, Osservatorio Emergenza Covid-19:1-28.

Dickmann, R. (2021). 'Il potere della Corte costituzionale di sospendere in via cautelare l'efficacia delle leggi (Osservazioni a margine di Corte cost., ord. 14 gennaio 2021, n. 4)' (The power of the Constitutional Court to suspend the effectiveness of the laws as a precaution (Observations on the sidelines of the Constitutional Court, Ord. 14 January 2021, no. 4) in federalismi.it 4:117-125.

Di Cosimo, G. (2020). 'Tra decreti e decreti: l'importanza di usare lo strumento giusto' (Between decrees and decrees: the importance of using the right tool) in lacostituzione .info 22 April. 
Di Cosimo, G. \& A. Cossiri (2020). 'Fase 2. Cioè?’ (Phase 2. That is?). in lacostituzione. info 29 April.

Di Cosimo, G. \& G. Menegus (2020). 'L'emergenza coronavirus tra Stato e Regioni: alla ricerca della leale collaborazione' (The coronavirus emergency between the State and Regions: in search of loyal collaboration) in Biolaw Journal 1: 183-199. http://dx.doi. org/10.15168/2284-4503-576

Dolso, G.P. (2020). 'Coronavirus: nota sulla dichiarazione dello stato di emergenza per rischio sanitario' (Coronavirus: note on the declaration of a state of emergency for health risk) in Ambiente diritto. https://www.ambientediritto.it/dottrina/coronavirusnota-sulla-dichiarazione-dello-stato-di-emergenza-per-rischio-sanitario/

D’Orlando, E. (2020). 'Emergenza sanitaria e Stato regionale: spunti per una riflessione' (Health emergency and the Regional state: ideas for reflection) in Osservatorio sulle fonti 2:577-594.

Equizi, C. (2020). 'Il difficile dialogo tra Stato e Regioni al tempo del coronavirus: dov'è la leale collaborazione?' (The difficult dialogue between the State and the Regions at the time of the coronavirus: where is the loyal collaboration?) in Dirittifondamentali. $i t$, June 10 .

Fabiano, L. (2020). 'La catena della normativa emergenziale in risposta alle minacce di diffusione del Covid-19. Riflessioni sulla tenuta in termini di legittimità e di opportunità delle scelte normative del Governo italiano' (The chain of emergency legislation in response to the spread threats of Covid-19. Reflections on the legitimacy and appropriateness of the Italian Government's regulatory choices) in BioLaw Journal 1:105-118. http://dx.doi.org/10.15168/2284-4503-567.

Ferraiulo, G. (2020). 'Nazionalismo banale e livelli di governo dell'emergenza (Banal nationalism and emergency government levels), in S. Staiano (ed.) Nel ventesimo anno del terzo millennio. Sistemi politici, istituzioni economiche e produzione del diritto al cospetto della pandemia da Covid-19' (In the twentieth year of the third millennium. Political systems, economic institutions and production of law in the face of the pandemic from Covid-19) pp. 113-148. Naples: Editoriale scientifica.

Ferrara, R. (2012). 'Rapporti Stato-Regioni in materia di sanità' (State-Regions relations on health matters) in Diritto online Treccani. Retrieved from: https://www.treccani. it/enciclopedia/rapporti-stato-regioni-in-materia-di-sanita_\%28Il-Libro-dell'anno-delDiritto\%29/.

Formisano, A. (2020). 'La gestione dell'emergenza durante il Covid-19 tra uniformismo e decentralismo. Considerazioni sull'A.S. 1825 e effetti sul regionalismo differenziato' (Emergency management during Covid-19 between uniformism and decentralism. Considerations on the A.S. 1825 and effects on differentiated regionalism) in Nomos. Le attualità del diritto 2:1-20.

Furlan, F. (2020). 'Il potere di ordinanza dei Presidenti di Regione ai tempi di Covid19' (The power of ordinance of the Presidents of the Region at the time of Covid19) in Federalismi.it 26:1-8.

Grosso, E. (2020). 'Legalità ed effettività nel tempo del diritto costituzionale dell' emergenza' (Legality and effectiveness over time of the constitutional law of emergency), in federalismi.it 6: iv-x.

Lanzafame, A.G. (2020). 'Il lockdown, l'avvio della fase due, e i problemi della fase tre. La gestione dell'emergenza, sanitaria ed economica, da Covid-19 tra disuguaglianze ingiuste e disuguaglianze necessarie' (The lockdown, the start of phase two, and the problems of phase three. Health and economic emergency management, from Covid19, between unjust inequalities and necessary inequalities) in Diritti Fondamentali 2:468-469. 
Lauro, A. (2020). 'Urgenza e legalità ai tempi del COVID-19: fra limiti imprescindibili e necessaria flessibilità' (Urgency and legality at the time of COVID-19: between essential limits and necessary flexibility) in BioLaw Journal 1:45-152. http://dx.doi. org/10.15168/2284-4503-570.

Longo, E. (2020). 'Episodi e momenti del conflitto Stato-Regioni nella gestione della epidemia da Covid-19' (Episodes and moments of the State-Regions conflict in the management of the Covid-19 epidemic) in Osservatorio sulle fonti, special issue: 377-407.

Longo, E. \& M. Malvicini M. (2020). 'Il decisionismo governativo: uso e abuso dei poteri normativi del Governo durante la crisi da COVID-19' (Government decisionmaking: use and abuse of the regulatory powers of the Government during the COVID-19 crisis) in federalismi.it 28:212-233.

Lucarelli, A. (2020). 'Costituzione, fonti del diritto ed emergenza sanitaria' (Constitution, sources of law and health emergency) in Rivista AIC 2: 558-583.

Luciani, M. (2020). 'Il sistema delle fonti del diritto alla prova dell'emergenza' (The system of sources of the right to emergency proof) in Rivista AIC 2:109-141.

Malo, M. (2020). 'Le Regioni e la pandemia. Variazioni sul tema' (The Regions and the pandemic. Variations on the theme) in Le Regioni 2:231-234.

Mandato, M. (2020). 'Il rapporto Stato-Regioni nella gestione del Covid-19' (The StateRegions relationship in the management of Covid-19) in Nomos. Le attualità del diritto 1:1-8.

Mandato, M. \& G. Stegher (2020). 'La Repubblica al banco di prova più difficile: cronaca costituzionale di un'emergenza sanitaria' (The Republic at the most difficult test bench: constitutional chronicle of a health emergency) in Nomos. Le attualità del diritto 1:1-38.

Mangiameli, S. (2006). 'Lo stato di emergenza e le competenze regionali' (The state of emergency and the regional competences) in Giurisprudenza costituzionale 4:2926.

Massa Pinto, I. (2020). 'La tremendissima lezione del Covid-19 (anche) ai giuristi' (The tremendous lesson of Covid-19 (also) to jurists) in Questione Giustizia: March 18.

Mazzarolli, L. (2020). ' «Riserva di legge» e «principio di legalità» in tempo di emergenza nazionale. Di un parlamentarismo che non regge e cede il passo a una sorta di presidenzialismo extra ordinem, con ovvio, conseguente strapotere delle pp.aa. La reiterata e prolungata violazione degli art. 16, 70 ss., 77 Cost., per tacer d'altri' («Legal reserve» and «principle of legality» in times of national emergency. Of a parliamentarism that does not hold up and gives way to a sort of extra ordinem presidentialism, with obvious, consequent excessive power of the pp.aa. The repeated and prolonged violation of Articles 16, 70 ss., 77 of the Constitution, to keep silent about others) in federalismi.it. Osservatorio Emergenza Covid-19:1-20.

Melzi d'Eril, C. \& G.E. Vigevani (2020). 'Polifonia stonata tra Governo e Regioni' (Out of tune polyphony between the Government and the Regions). Il Sole 24 Ore, March 29.

Mobilio, G. (2020). 'La decretazione d'urgenza alla prova delle vere emergenze. L'epidemia da Covid-19 e i rapporti tra decreto-legge e altre fonti' (The emergency decree to prove real emergencies. The Covid-19 epidemic and the relationship between the law decree and other sources) in Osservatorio sulle fonti, special issue: 351-376.

Morana, D. (2002). La salute nella Costituzione italiana. Profili sistematici (Health in the Italian Constitution. Systematic profiles). Milan: Giuffrè.

Morbidelli, G. (2016). 'Delle ordinanze libere a natura normativa' (On free ordinances of a normative nature) in Diritto Amministrativo 1:33-70. 
Morelli, A. \& A. Poggi (2020). 'Le Regioni per differenziare, Lo Stato per unire. A ciascuno il suo' (The Regions to differentiate, The State to unite. To each his own) in Diritti regionali 2:1-6.

Musella, F. (2020). 'I poteri di emergenza nella Repubblica dei Presidenti' (The emergency powers in the Republic of Presidents), in S. Staiano (ed.) Nel ventesimo anno del terzo millennio. Sistemi politici, istituzioni economiche e produzione del diritto al cospetto della pandemia da Covid-19' (In the twentieth year of the third millennium. Political systems, economic institutions and the production of law in the face of the Covid-19 pandemic) pp. 701-722. Napoli: Editoriale Scientifica.

Onida, V. (2020). 'La Costituzione e le lezioni dell'emergenza' (The Constitution and the lessons of the emergency), in M. Malvicini, T. Portaluri \& A. Martinengo (Eds) Le parole della crisi. Le politiche dopo la pandemia (The words of the crisis. Politics after the pandemic) pp. 37-48.

Pagano, F.F. (2020). 'Il principio di unità e indivisibilità della Repubblica ai tempi dell'emergenza Covid-19' (The principle of unity and indivisibility of the Republic at the time of the Covid-19 emergency) in Biolaw Journal 1:209-218.

Palermo, F. (2020). 'Il virus è centralista?' (Is the virus a centralist?) in la rivista il Mulino February 26.

Papa, A. (2019). 'Regionalismo differenziato e garanzia dei livelli essenziali delle prestazioni: il caso paradigmatico della tutela del diritto alla salute' (Differentiated regionalism and guarantee of the essential levels of services: the paradigmatic case of the protection of the right to health), in AA.VV., Regionalismo differenziato: un percorso difficile, Atti del Convegno "Regionalismo differenziato: opportunità e criticità" pp. 63-70 (Differentiated Regionalism: A Difficult Path, Proceedings of the Conference "Differentiated Regionalism: Opportunities and Criticalities").

Pinelli, C. (2020). 'Il precario assetto delle fonti impiegate nell'emergenza sanitaria e gli squilibrati rapporti fra Stato e Regioni' (The precarious structure of the sources used in the health emergency and the unbalanced relations between the State and the Regions) in Astrid Rassegna 5:1-8.

Poggi, A. (2020). 'Tornare alla normalità dei rapporti Stato-Regioni. Errori da evitare e lezioni da meditare' (Return to the normality of State-Regions relations. Errors to avoid and lessons to meditate) in federalismi.it 25: iv-xii.

Pollicino, O. \& G.E. Vigevani (2020). 'Gli studi professionali restano aperti. Prevalgono le indicazioni del Governo' (The professional offices remain open. The indications of the Government prevail). Il Sole 24 Ore, March 24.

Raffiotta, E. (2020). Norme d'ordinanza. Contributo ad una teoria delle ordinanze emergenziali come fonti normative (Ordinance Rules. Contribution to a theory of emergency ordinances as normative sources). Bologna: Bonomia University Press.

Ravì Pinto, R. (2020). 'Brevi considerazioni su stato d'emergenza e stato costituzionale' (Brief considerations on the state of emergency and the constitutional state) in BioLaw Journal 1:43-50.

Rescigno, F. (2020). 'La gestione del coronavirus e l'impianto costituzionale. Il fine non giustifica ogni mezzo?' (Coronavirus management and the constitutional framework. Doesn't the end justify every means?) in Osservatorio AIC 3: 253-271.

Ronga, U. (2020). 'Il governo nell'emergenza (permanente). Sistema delle fonti e modello legislativo a partire dal caso Covid-19' (Government in (permanent) emergency. System of sources and legislative model starting from the Covid-19 case) in Nomos. Le attualità del diritto 1:1-35.

Rossi, E. (2020). 'Appunti sull'abrogazione di decreti-legge in sede di conversione ad opera di successivi decreti-legge nell'emergenza Coronavirus)' (Notes on the repeal 
of law decree during conversion by subsequent law decrees in the Coronavirus emergency) in Osservatorio sulle fonti, special issue: 641-657.

Ruggeri, A. (2020). 'Il coronavirus contagia anche le categorie costituzionali e ne mette a dura prova la capacità di tenuta' (The coronavirus also infects constitutional categories and puts a strain on their resilience) in Diritti regionali 1:367-378.

Salerno, G.M. (2020). 'Alle Regioni il compito di stabilire misure più o meno restrittive' (The Regions have the task of establishing more or less restrictive measures) in Guida al diritto 24:111.

Severa, F. (2020). 'Sui raccordi tra livelli di governo in tempo di emergenza' (On the connections between levels of government in times of emergency) in BioLaw Journal 1:219-226.

Silvestri, G. (2020). 'Situazioni di emergenza e garanzie costituzionali' (Emergency situations and constitutional guarantees), in M. Malvicini, T. Portaluri \& A. Martinengo (Eds) Le parole della crisi. Le politiche dopo la pandemia (The words of the crisis. Politics after the pandemic) pp: 21-35.

Sorrentino, F. (2020). 'Riflessioni minime sull'emergenza' (Minimum reflections on the coronavirus emergency) in Costituzionalismo.it 1:130-139.

Staiano, S. (2020). 'Né modello né sistema. La produzione del diritto al cospetto della pandemia' (Neither model nor system. The production of law in the presence of the pandemic), in ID. (ed.), Nel ventesimo anno del terzo millennio. Sistemi politici, istituzioni economiche e produzione del diritto al cospetto della pandemia da Covid19 (In the twentieth year of the third millennium. Political systems, economic institutions and the production of law in the face of the Covid-19 pandemic), pp: 1144.

Trabucco, D. (2020). 'Sull'(ab)uso dei decreti del Presidente del Consiglio dei Ministri al tempo del Coronavirus: tra legalità formale e legalità sostanziale' (On the (ab)use of the decrees of the President of the Council of Ministers at the time of the Coronavirus: between formal legality and substantial legality) in Astrid Rassegna 5.

Tresca, M. (2020), 'Le fonti dell'emergenza. L'immunità dell'ordinamento al covid-19' (The sources of the emergency. The immunity of the legal system to covid-19), in Osservatorio AIC 3: 200-213.

Tripodina, C. (2020). 'La Costituzione al tempo del Coronavirus' (The Constitution at the time of the Coronavirus) in Costituzionalismo.it 1:77-88. 